\title{
Beyond the Cultural Turn: \\ A Critical Perspective on Culture-Discourse within Public Relations
}

Alex Frame (University of Burgundy Franche-Comté) and Øyvind Ihlen (University of Oslo)

\section{Abstract \\ Purpose}

This chapter applies recent theoretical developments linked to the concept of culture to the field of public relations research and practice, notably through the prism of creativity as a vector of cultural change.

\section{Design/methodology/approach}

The chapter is theoretical in nature, and draws on relevant scientific literature in the field of public relations research, but also the social sciences more generally, and illustrates the issues being discussed with reference to relevant public relations campaigns.

\section{Findings}

While the field of public relations has moved beyond simplistic models of cultural values and characteristics, it is argued that more complex visions of culture have been neglected. Specifically, drawing on structuration theory, culture can be seen as a "system-generating mechanism" relying on creativity to uphold and renew cultural references and norms. In this perspective, public relations is both producing/reproducing culture and being produced by culture. It follows that the concept should be apprehended not as an ontological category, but as a social construct, as the source of heuristic and discursive categorisations.

\section{Social implications}

A call is issued for public relations to also question the ideological underpinnings of the production of symbols in which practitioners partake on a daily basis.

\section{Originality/value}

While the chapter fits into an emerging body of work discussing the cultural dimension of public relations, the link with creativity and the use of structuration theory to conceptualise this link contribute to its originality.

\section{Keywords}

Critical intercultural theory, culture, cultural appropriation, public relations, social discourse, stereotypes

\section{Introduction}

In 1992, Sriramesh and White (1992) pointed to the importance of culture for public relations and the need for more research in this domain. Two decades later, public relations scholars answered this call in force (e.g., Bardhan \& Weaver, 2011; Carayol \& Frame, 2012; Edwards \& Hodges, 2011; Sriramesh \& Vercic, 2012). Research has thus broadly moved beyond the use of simplistic models that 'essentialise' national cultures, seeking to reduce them to distinctive sets of deterministic invariables measured along a few value-based dimensions (e.g., Hofstede, 2001), to a much wider range of theories and perspectives with their roots in sociology and ethnography among others. 
Public relations scholars interested in culture also refer to the "mother discipline" of the concept anthropology - and point out how practitioners can be perceived as storytellers and mythmakers, as opposed to being seen as managers or technicians (L'Etang, 2012).

Broadly speaking, public relations scholars have so far (a) analysed culture as an antecedent for public relations practice, (b) investigated the impact of public relations on culture and society, and (c) approached public relations as culture in its own right (Sriramesh, 2012). Sriramesh (2012) concludes that most research has focused on the first of these three approaches. Some studies have attempted to describe what is culture specific, while others have focused on what is common for different cultures, and yet others have focused on intercultural interaction (Zaharna, 2000). Basically, much of the research on public relations and culture has aimed to help public relations practitioners communicate in and across national and sometimes professional cultures.

In this short theoretical essay, however, we argue that the debate surrounding the place of culture in public relations research and practice should be repositioned in the context of wider discussions surrounding the concept in the social sciences. More specifically, we point to the need to take a closer look at the ideological and epistemological basis of the culture concept in public relations. First, we will argue that the way that public relations builds or maintains "cultural differences" needs critical analysis. Culture should not be reduced to a barrier for practice or something to be harnessed in pursuit of organisational effectiveness, since such approaches, when translated into public relations campaigns, may implicitly reinforce the myth underlying much populist discourse, that social categorisation is a source of inalienable difference.

Secondly, we will argue that the relationship between public relations and culture is best grasped through the lens of structuration theory (Giddens, 1984). It is not a question of how public relations is formed by culture or vice versa. We see public relations as both producing/reproducing culture and being produced by culture: public relations professionals attune their messages culturally, and these messages, relayed through the media, contribute to the way in which cultural representations evolve.

\section{Culture and Criticism}

While the surface meaning of the term culture implies that a group shares certain understandings or practices, there are historic (and opposing) approaches to culture as a system of values (Parsons \& Shils, 1951; Weber, 1905) or meanings (Geertz, 1973; Swidler, 1986). Culture is paradoxically one of the most successful concepts to have emerged in the social sciences over the course of the last century, and particularly useful to help us understand many contemporary topics of social debate, but at the same time use of the concept is strongly criticised within the social sciences themselves, where certain academics (e.g., Dervin \& Machart, 2015a) reject the term outright because they see it increasingly being used to construct and maintain difference socially, rather than to try and understand interpersonal and social group dynamics. Indeed, it is in part the success of the concept itself outside the academic sphere, and the way that it is used by the media, politicians, and in the public sphere more generally, which has led to this state of affairs.

From Social and Cultural Anthropology in the early twentieth century, the concept of culture spread to other social sciences, notably from the Sixties onwards (Bauman, 1999, p. viii), rapidly moving from the domain of scientific jargon into popular discourse, to the point where, as Dervin and Machart (2015b, p. 1) note, it was declared "Word of the Year" by the Merriam-Webster dictionary in 2014. However, at the same time, critical voices were being raised in academic circles, calling for the concept to be abandoned. Indeed, from being what was already a notoriously polysemic term, according to Dervin and Machart its popularity has made it into a dangerous "floating signifier" today (2015b, p. 2), a pseudo-scientific term without a clear or fixed meaning, which leaves it open to all 
kinds of misuses. Already in 1999, Hannerz had denounced what he saw as increasingly pervasive "culturespeak", by which he broadly meant inappropriate and reductive or deterministic use of the concept. Culturespeak tends to understate individual differences and favour a static vision of culture, rather than a dynamic one in which culture is seen as a constantly-negotiated social process.

Although the concept was central in anthropology for many years, it has now become strongly contested within this discipline (Anderson-Levitt, 2012; Kuper, 2001). The idea that the members of a society or social group all share the same cultural references has revealed its limits in studies of (post-)modern societies characterised by the diversity of their populations and a certain liquidity (Bauman, 2011) in the identity choices people make. For many anthropologists, including Appadurai (2001, pp. 40-47) and Amselle (2001, pp. 205-6), the concept with its homogenising overtones is not sufficiently dynamic to capture the complex social processes and contexts within which people evolve today, and its use artificially reinforces perceptions of social distinctions.

Indeed, the concept of culture has never been ideologically neutral. In his book Liquid Culture, Bauman (2011, pp. 1-17) identifies different uses of the notion of culture in different historical periods and distinguishes four of these: culture as Enlightenment (intellectual progress), culture as global domination (Elias's (1973) "civilization process"), culture as homeostasis and maintenance of group boundaries (linked to Bourdieu's (1979) "distinction"), and culture as personal invention (liquid modernity, multicultural societies). In each period, claims Bauman, the concept takes on a particular ideological nuance, linked respectively to rationalism, imperialism, elitism and then relativism. Except in its liquid version, it has been used to ethically justify various policies and attitudes towards other groups, generally judged as inferior, for example through colonialist projects. Elsewhere, Bauman describes culture as "simultaneously a man-made and a man-making entity" (Bauman, 1999, p. 28), in that it replaces, at least to some degree, supernatural rationalisations of the differences in behaviour, development, wealth, and so on between ethnic groups. Indeed, despite their historical roots, all four ideologies of culture can be found today in media discourse and public discourse in many Western countries, and must also be taken into account by public relations professionals, as the importance of culture or of culture-based discourse emerges and comes to be recognised within this field.

\section{The Cultural Turn in Public Relations}

Sriramesh and other scholars have criticized much previous public relations research for its focus on the work of Hofstede and cultural characteristics that are apparently common across countries (Sriramesh, 2009), rather than approaches which present culture as a social phenomenon on the level of the social group (Frame, 2012), or as a communication resource or tool-kit (Swidler, 1986). Sriramesh has argued for a multi-level approach examining the political culture, economic culture, societal and organizational culture, media culture and activist culture of a country and the links between these and public relations. Culture can thus be seen as an antecedent for public relations practice, while public relations also exercises an influence on all of these cultures (Sriramesh, 2012).

Although increased attention to the question of cultures is in many ways a positive evolution in public relations theory and practice, this trend also brings with it new risks associated with increased public sensitivity towards the ways in which cultures and groups are portrayed. This can be illustrated by the "cultural appropriation" debate, when often self-designated representatives of a minority or underprivileged social group accuse non-members of trying to illegitimately appropriate its cultural codes and traditions, often in order to make a profit. The British music group Coldplay and American pop stars such as Taylor Swift, Miley Cyrus and Katy Perry have come under such criticism in recent 
years, for allegedly exploiting cultural traditions from other countries or minority groups ${ }^{1}$ (here, using braids or mimicking what are seen as Afro-American dance codes) but the debate even extends to which children can legitimately wear which costumes at Halloween or for Carnival celebrations in the US and elsewhere. ${ }^{2}$ In Norway, for example, the Minister for Finance was criticized for posing dressed in a Pocahontas costume at a party in the department. ${ }^{3}$

Another recent example more directly relevant for public relations is the commercial released by Pepsi that featured a super model joining in a street protest and handing a policeman a can of the soft drink. A statement from the company declared that "This is a global ad that reflects people from different walks of life coming together in a spirit of harmony, and we think that's an important message to convey." ${ }^{4}$ Given the background of recent US street rally's under the moniker "black lives matter," the commercial caused uproar and was consequently pulled. Comedian Stephen Colbert quipped "attractive lives matter."

Other examples of corporate cultural appropriation include the UK clothing chain Top Shop's use of the Palestinian black \& white scarf design for a summer dress and the French company Chanel that included a boomerang with their logo as a part of their summer 2017 collection. ${ }^{6}$ The former caught criticism for appropriating a symbol for the struggle of Palestinians, and the latter was criticized by aboriginal organizations. The tensions caused by the cultural appropriation by these and other corporations show just how far things can go when cultural identity claims are taken for absolute truths, and defended as such.

Cultural appropriation thus constitutes a new risk for public relations professionals, in terms of potential unwanted negative publicity attracted by brands which may be accused of trying to appropriate cultural codes for commercial reasons.

In ideological terms, referring to Bauman's classification (2011; supra), this can be analysed as revealing tensions between, on the one hand, visions of culture as homeostasis and a desire to maintain group boundaries, and, on the other hand, a liquid vision of culture as a resource for personal invention. When examining many accusations of cultural appropriation, we can also adopt a post-colonialist reading of the situation: less economically prosperous groups see themselves historically as being victims of colonial exploitation and cultural persecution, at the hands of the very same groups who appear still to be in a position of social and economic dominance, and who now seek to exploit the cultures they once denigrated, in order to make commercial profit. The situation is more acute in multicultural societies, with North-American multiculturalism constituting an extreme example, but the internet is also contributing to spread the debate, and the protests, globally. We would argue that this is symptomatic of a more general ideological tendency to see cultural identity in more "solid," essentialist (Dervin \& Machart, 2015a), deterministic and reductive

\footnotetext{
${ }^{1}$ Cf. https://www.theguardian.com/music/2015/apr/17/hunger-games-amandla-stenberg-criticises-mileycyrus-taylor-swift-cultural-appropriation. Page consulted on 31/03/2017.

${ }^{2}$ Cf. https://www.washingtonpost.com/news/parenting/wp/2016/10/10/cultural-misappropriation-and-mydaughters-halloween-costume/?utm_term=.d5cfc803e17f. Page consulted on 31/05/2017.

${ }^{3}$ http://www.newsinenglish.no/2017/10/17/sivs-pocahontas-stunt-backfired/ . Page consulted March 26, 2018.

${ }^{4}$ http://people.com/food/pepsi-responds-kendall-jenner-backlash-protest-ad/. Page consulted on 31/05/2017.

${ }^{5}$ http://time.com/4728979/stephen-colbert-kendall-jenner-pepsi-attractive-lives-matter/. Page consulted on 31/05/2017.

${ }^{6}$ http://www.commisceo-global.com/blog/how-to-avoid-cultural-appropriation-promote-cultural-awarenessinstead. Page consulted on 31/05/2017.
} 
terms, a conception which has a very real impact on the practice of public relations all around the globe.

Indeed, in everyday public relations practice, reliance on cultural identifications is of course widespread, as we tend to unthinkingly use various categories to define ourselves and others in order to predict behaviour and anticipate reactions. In this sense, the concept of culture is a social reality, used to make sense of the social world around us and corresponds to a basic human need to think in terms of categories. As Holliday puts it, "While culture may not be real in the solid, essentialist sense, it is real in the way in which it is used and as an excuse, and very often real in the minds of those who use it" (Holliday, 2015, p. 199). It follows that this concept should be considered . This way of thinking encourages us to identify individuals as members of a particular group, and to consider them first and foremost in terms of the traits which we expect them to share, on the basis of their membership of this group, with the other members of the same group. The more different a group appears to be to our "own" group - perceived differences which we often explain away through "culture" - the more members of that group may tend to appear alike. Simplifying the complexity through the use of stereotypes is a way of making it more familiar and less frightening. In order to help us think about Otherness (considering an individual as a member of an out-

group/denying them the status of in-group membership) or communicate with individuals whom we identify as members of a (little-known) out-group, social categorisation comforts us in the idea that the members of such and such a group share a fairly homogenous culture. In other words, this natural cognitive process tends to comfort us in a falsely essentialist and reductive vision of cultures.

For public relations professionals, it is thus essential to tread the fine line between referring to cultures and social categories in order to construct meaningful messages which appeal to familiar categories, and reinforcing the underlying social stereotypes. Independently of the desire to avoid accusations of cultural appropriation, on an ethical level, public relations professionals should also think about the kind of images that they are putting into circulation in the media, since they also play a direct role in reinforcing or questioning stereotypes through their work. Public relations tends to mirror social beliefs and representations in order to resonate with audiences. This echoes an insight from ancient rhetoric: you need to take into consideration what your audience think, their values and the premises they will accept, and build on this when you try to persuade them about something.

Of course, values and premises should not be reproduced unthinkingly. Public relations professionals should be held professionally and socially accountable for the implicit cultural models and beliefs underlying the materials they produce. However, this question is only very rarely included in discussions of professional ethics by professional bodies. Bringing this aspect in would be in line with many of the calls that have been issued in critical public relations over the years (L'Etang, McKie, Snow \& Xifra, 2015). Practitioners should "always question the nature of their own institutions and strive to improve them and make them more just" (Holtzhausen, 2012, p. 234). For the most part, however, such scholarship has addressed, for instance, whether "the democratic, deliberative and decision-making roles of civil society" have been opened up or closed down as a consequence of public relations activity (Motion \& Leitch, 2015, p. 148) or public relations has been urged to engage with the public interest (Johnston, 2016). As Sriramesh (2012) points out, the impact of public relations on culture and society has not been widely studied.

\section{Culture, Public Relations, and Creativity}

The preceding discussion enables us to pinpoint the relationship between culture, public relations and creativity. Culture can be understood as the supply of symbols, stories, rituals, and world-views on which people draw to create strategies of action (Swidler, 1986). Creativity in public relations 
relies on these symbolic resources which constitute the foundations and building blocks, from which a message is shaped in a new and original way.

In order to better characterise this relationship, it is important to take into account the fundamental duality of what we call "culture", in that it both structures our social interactions and is performed through them. Paraphrasing Hall (1959), cultures shape our communication, and our communication in turn shapes our cultures. ${ }^{7}$ Bauman expresses this idea, focusing on the tensions between conformism and non-conformism underlying our everyday social interactions, when he observes that culture as praxis: ${ }^{8}$

is as much about inventing as it is about preserving; about discontinuity as much as about continuation; about novelty as much as about tradition; about routine as much as about pattern breaking; about norm-following as much as about the transcendence of norm; about the unique as much as about the regular; about change as much as about monotony of reproduction; about the unexpected as much as about the predictable. (Bauman, 1999, p. xiv)

Here, Bauman is echoing Giddens' vision of the duality of structure, which the latter expressed in the form of Structuration Theory (1984), reminding us that when individuals produce symbolic acts (speech, actions), they are unconsciously referring to various rules and norms, but the fact of doing so means that the rules and norms themselves are being maintained and possibly updated. The system which structures behaviour is itself reproduced through the behaviour it structures.

If we consider it as structure, then, it is important to note that culture is not stable, but a dynamic process. As Desjeux points out:

Culture is both structure and something dynamic, which is what makes it so hard to observe and analyse. As structure, it includes stable elements which can give the impression that it has an essence, whereas in fact this stability results first and foremost from the fact that historically things change over long periods. As a dynamic process, it is indeed subject to historical change [authors' translation] (Desjeux, 2002, p. 2).

This dynamic nature of culture as a structuring process in communication helps us foreground the links between public relations and creativity, and indeed the role of public relations professionals as cultural mediators (Schoenberger-Orgad, 2009) for society at large. As already pointed out, public relations professionals often seek to draw upon social representations familiar to the publics they are targeting, in order to express new ideas in what is likely to be perceived as a convincing way. While doing so, they are acting in a context of intertextuality, where the audience is supposedly able to draw on knowledge from a variety of sources in order to interpret the messages being produced. They are also themselves contributing to enriching this context through the material they produce, which can in turn be used as a new reference in interpreting subsequent messages. Thus the "Like a Girl" campaign by Always, for example, clearly sought to build on audience members' existing representations and widespread social discourse about what it means do something "like a girl", while reconfiguring these representations to a small degree: the campaign 'works' thanks to the cultural context, and aims to influence the context itself. Similarly, the company Bodyform has recently played on the intertextual codes of female hygiene product advertising, and notably the

\footnotetext{
${ }^{7}$ In the Silent Language, Hall famously states, "Culture is communication and communication is culture" (Hall, 1959, p. 186).

${ }^{8}$ The term praxis, as in Bauman's book Culture as Praxis, is used here to refer to culture which exists through practice: it is only through behaviour marked by culture that culture is maintained, passed on and renewed.
} 
conventional use of "blue fluid" by many brands to promote the absorbancy of sanitary products. ${ }^{9}$ These ads follow on from pioneering viral YouTube marketing in 2012 by the same company, ${ }^{10}$ which 'work' because people recognise this convention, and possibly affect the way they will react to other such adverts in the future. The inherent creativity of public relations campaigns resides in professionals' capacity to produce forms which reflect existing representations, structures and ideas circulating within a particular cultural or societal frame, in order to ensure that their messages resonate with the target publics, while renewing the underlying cultural conceptions in a way that allows the brand to stand out and be noticed, often to appear "modern". These representations, structures and ideas may thus be implicitly criticised, questioned or reinforced by the campaign, as it constitutes its own contribution to the discourse "out there" about such and such a topic. The pressure for campaigns to be "creative", i.e., to remain recognisable while challenging communicational conventions, is one of the motors of cultural change on the societal level.

It follows that the notion of creativity in public relations does not suppose total artistic freedom, rather it refers to the ability of creatives and other public relations professionals to adopt and adapt existing cultural frames of reference, to play the role of "cultural mediators" by expressing concepts and ideas in forms which resonate with their audiences' representations while associating them with a message which is new and different. Public relations in this sense molds taste and creates identification between producers and consumers (Curtin \& Gaither, 2007; Edwards, 2012).

With reference to structuration theory, public relations professionals rely on dominant structures to make sense to their audiences, while often seeking to breaking away from them for effect (to increase notoriety or work on image) or to convey a particular message. Indeed, public relations is more often about influencing and changing dominant representations than it is about reinforcing them, though both are of course possible. In both cases, creativity is the key, but a form of creativity which is firmly grounded in existing cultural representations.

If culture is the underlying structure, in Giddens' sense, public relations messages are thus one of the many ways (materialised forms) in which the structure is dynamically updated and caused to evolve, thanks to the creative work of the public relations teams. The impact of public relations messages are all the more powerful when they are released through mass media outlets, exposing many individuals simultaneously to the same stories and symbolic stimuli. The creative development of the aforementioned Pepsi commercial was explained this way by the company:

The creative showcases a moment of unity, and a point where multiple storylines converge in the final advert. It depicts various groups of people embracing a spontaneous moment, and showcasing Pepsi's brand rallying cry to 'Live For Now,' in an exploration of what that truly means to live life unbounded, unfiltered and uninhibited. ${ }^{11}$

Sometimes creative minds go further, playing on stereotypes and cultural taboos for maximal sensationalist effect though at the same time they may create ugly examples, for instance of a misogynist character. Despite US discussions of rape culture, the retailer Bloomingdale issued an infamous ad which read "Spike your best friend's eggnog when they're not looking". ${ }^{12}$ Whether such campaigns and the outcry they often provoke actually reinforce or rather call into question what

\footnotetext{
${ }^{9}$ http://www.bbc.com/news/uk-41666280. Page accessed 22 ${ }^{\text {nd }}$ March 2018.

${ }^{10}$ https://www.youtube.com/watch?v=Bpy75q2DDow. Page accessed 22 ${ }^{\text {nd }}$ March 2018.

${ }^{11} \mathrm{http}: / /$ people.com/food/pepsi-responds-kendall-jenner-backlash-protest-ad/. Page consulted on 31/05/2017.

12 https://www.buzzfeed.com/stephaniemcneal/bloomingdales-egg-nogad?utm_term=.ahPA2nBEzk\#.mja74awdAl. Page consulted on 31/05/2017.
} 
many people deem to be dominant negative cultural representations is wide open to debate, though it would appear to be an important issue which needs addressing by the ethics bodies of the public relations profession.

In contrast to the preceding examples, a campaign that received praise is the one instigated by the personal care brand Dove with the slogan "Real beauty". In what has been called "one of the biggest conceptual ad campaigns of the decade" narrow definitions of female beauty were challenged. ${ }^{13}$ Through ads depicting women with shapes and figures different from the typical slim models, Dove, with the help of the public relations agency Edelman, "sought to start a conversation about beauty". ${ }^{14}$ The contrast to the campaign from Victoria's Secret called "The Perfect 'body"' is striking. ${ }^{15}$ The latter was also hijacked by the smaller competitor Dear Kate, again showing pictures of ordinary women. In this way, public relations professionals as cultural mediators contribute to upholding, challenging, and renewing cultural values and representations within the societies in which they work. It also illustrates a point that by now has grown old; namely that public relations can be used for both positive or negative purposes, and as a profession needs to come to grips with this (Fawkes, 2014; Ihlen \& Verhoeven, 2012).

\section{Conclusion}

Although the "cultural turn" in public relations has been salutary in many respects, it finds its (opposing) limits in (a) accusations of cultural appropriation or viral communitarian backlashes, and (b) essentialising identities and reinforcing imagined (homogenous) communities. In this paper, we have argued the need for a more complex vision of culture, its role in society and notably the essential role that it plays in the creative process. Building on work done by Giddens (1984) or Bauman (1999) on culture as a structuration process, we have focused on its social role as a "systemgenerating mechanism" that creates "knowledge-making groups [...] within which individual choice and creativity are produced" (Hartley \& Potts, 2014, p. 23). Such process-based perspectives place communication and story-telling, indeed, public relations, at the centre of their analysis and, in this sense, public relations can itself be studied as a process of cultural reproduction (Frame, 2013). As such, studying public relations and culture is also a study of how public relations is influenced by and influences society.

Public relations plays a role in building/maintaining social consciousness of "cultural differences" both in the way it classifies audiences along cultural lines (structural determinism) and through the messages it produces which often tend to flatter audiences' (stereotyped) preconceptions of society. It is thus essential for public relations theorists and practitioners alike to adopt a critical stance towards their own and their colleagues' uses of "culture discourse" within the field, questioning their epistemological and ideological underpinnings.

What next? We would obviously encourage more research, focusing on, for instance, the cultural toolbox of culture comes into play in public relations on many different levels, or the impact of various types of messages, which appear to reinforce or challenge positive and negative representations, on various audiences. Cultures and identities are national, regional, ethnic, organisational and professional, among others, and these different levels of identification and of symbolic recognition mean that public relations practitioners need to take into account many

\footnotetext{
${ }^{13}$ http://www.huffingtonpost.com/2014/01/21/dove-real-beauty-campaign-turns-10_n_4575940.html. Page consulted on 31/05/2017.

${ }^{14}$ http://www.huffingtonpost.com/2014/01/21/dove-real-beauty-campaign-turns-10_n_4575940.html. Page consulted on 31/05/2017.

${ }^{15}$ http://www.huffingtonpost.com/2014/11/06/victorias-secret-perfect-body-campaign_n_6115728.html. Page consulted on 31/05/2017.
} 
different potential readings of the same message, in the light of what it might mean for many different groups. Naturally, the more complexity one seeks to take into account, the more unwieldy the models become. This, however, promises a fruitful future for scholarship on public relations and culture. 


\section{Bibliography:}

Amselle, J.-L. (2001). Branchements : Anthropologie de l'universelle des cultures (Flammarion). Paris: Flammarion.

Anderson-Levitt, K. M. (2012). Complicating the concept of culture. Comparative Education, 48(4), 441-454.

Appadurai, A. (2001). Après le colonialisme : les conséquences culturelles de la globalisation. Paris: Payot.

Bardhan, N., \& Weaver, C. K. (Eds.). (2011). Public relations in global cultural contexts: Multiparadigmatic perspectives. London: Routledge.

Bauman, Z. (1999). Culture as Praxis. London: Sage.

Bauman, Z. (2011). Culture in a Liquid Modern World. Cambridge, UK: Polity Press.

Bourdieu, P. (1980). L'identité et la représentation : éléments pour une réflexion critique sur l'idée de région. Actes de La Recherche En Sciences Sociales, $n^{\circ} 35,10$.

Bourdieu, P. (1979). La Distinction : Critique sociale du jugement. Paris: Les Editions de Minuit.

Carayol, V., \& Frame, A. (Eds.). (2012). Communication and PR from a cross-cultural standpoint. New York: Peter Lang.

Curtin, P. A., \& Gaither, T. K. (2007). International public relations: Negotiating culture, identity, and power. Thousand Oaks, CA: Sage.

Dervin, F., \& Machart, R. (Eds.). (2015a). Cultural Essentialism in Intercultural Relations. London: Palgrave Macmillan.

Dervin, F., \& Machart, R. (2015b). Introduction: Omniscient Culture, Omnipotent Cultures. In F. Dervin \& R. Machart (Eds.), Cultural Essentialism in Intercultural Relations (pp. 1-11). London: Palgrave Macmillan.

Desjeux, D. (2002). Les échelles d'observation de la culture. Communication et organisation, (22).

Edwards, L. (2012). Exploring the Role of Public Relations as a Cultural Intermediary Occupation. Cultural Sociology, 6(4), 438-454. doi:10.1177/1749975512445428

Edwards, L., \& Hodges, C. E. M. (Eds.). (2011). Public relations, society \& culture: Theoretical and empirical explorations. London: Routledge.

Elias, N. (1973). La Civilisation des moeurs. Paris: Calmann-Lévy.

Fawkes, J. (2014). Public relations ethics and professionalism: The shadow of excellence. London: Routledge.

Frame, A. (2012). Cultures, Identities and Meanings in Intercultural Encounters: a Semiopragmatics Approach to Cross-Cultural Team-Building. In V. Carayol \& A. Frame (Eds.), Communication and PR from a Cross-Cultural Standpoint. Practical and Methodological Issues (pp. 31-42). Brussels: Peter Lang.

Frame, A. (2013). PR and Global Interculturation. Methodological Challenges for (Cross)Cultural PR Research. In A. Okay, V. Carayol, \& R. Tench (Eds.), Researching the Changing Profession of Public Relations (pp. 143-156). Brussels: Peter Lang. 
Geertz, C. (1973). The Interpretation of cultures. New York: Basic Books.

Giddens, A. (1984). The Constitution of Society : Outline of a Theory of Structuration. Cambridge: Polity Press.

Hall, E. T. (1959). The Silent Language. New York: Anchor.

Hannerz, U. (1999). Reflections on varieties of culturespeak. European Journal of Cultural Studies, 2(3), 393-407.

Hartley, J., \& Potts, J. (2014). Cultural Science. A Natural History of Stories, Demes, Knowledge and Innovation. London: Bloomsbury Academic.

Hofstede, G. (2001). Culture's consequences: Comparing values, behaviors, institutions, and organizations across nations ( 2 ed.). Thousand Oaks, CA: Sage.

Holliday, A. (2015). Afterword. In F. Dervin \& R. Machart (Eds.), Cultural Essentialism in Intercultural Relations (pp. 198-202). London: Palgrave Macmillan.

Holtzhausen, D. R. (2012). Public relations as activism: Postmodern approaches to theory \& practice. New York: Routledge.

Ihlen, $\varnothing$., \& Verhoeven, P. (2012). A public relations identity for the 2010s. Public Relations Inquiry, 1(2), 159-176

Johnston, J. (2016). Public relations and the public interest. New York: Routledge.

Kuper, A. (2001). L'illusion des cultures. Sciences Humaines, $n^{\circ} 13,5$.

L'Etang, J., McKie, D., Snow, N., \& Xifra, J. (Eds.). (2015). Routledge handbook of critical public relations. London: Routledge.

L'Etang, J. (2012). Thinking about public relations and culture: Anthropological insights and ethnographic futures. In K. Sriramesh \& D. Verčič (Eds.), Culture and public relations: Links and implications (pp. 218-236).

Moscovici, S. (2000). Psychologie sociale des relations à autrui. Paris: Nathan Université.

Motion, J., \& Leitch, S. (2015). Critical discourse analysis: a search for meaning and power. In J.

L'Etang, D. McKie, N. Snow, \& J. Xifra (Eds.), Routledge handbook of critical public relations (pp. 142150). London: Routledge.

Parsons, T., \& Shils, E. (1951). Toward a general theory of action (Theoretical foundations for the social sciences). Cambridge (MA): Harvard University Press.

Schoenberger-Orgad, M. (2009). Transcending boundaries: The public relations practitioner as cultural mediator. In Institute for Public Relations Bledcom Conference Special Prize finalist paper. (Vol. 1).

Sriramesh, K. (2009). The relationship between culture and public relations. In K. Sriramesh \& D. Verčič (Eds.), The Global Public Relations Handbook, Revised and Expanded Edition: Theory, Research, and Practice (Vol. 2, pp. 47-61).

Sriramesh, K. (2012). Culture and public relations: Formulating the relationship and its relevance to the practice. In K. Sriramesh \& D. Verčič (Eds.), Culture and public relations: Links and implications (pp. 9-24). 
Sriramesh, K., \& Vercic, D. (Eds.). (2012). Culture and public relations: Links and implications. New York: Routledge.

Sriramesh, K., \& White, J. (1992). Societal culture and public relations. In J. E. Grunig (Ed.), Excellence in public relations and communication management (pp. 597-614).

Swidler, A. (1986). Culture in action: Symbols and strategies. American Sociological Review, 51(2), 273-286.

Tajfel, H. (1981). Human Groups and Social Categories: Studies in Social Psychology. Cambridge: Cambridge University Press.

Weber, M. (1905). The Protestant Ethic and the Spirit of Capitalism. London: George Allen \& Unwin.

Zaharna, R. S. (2000). Intercultural communication and international public relations: Exploring parallels. Communication Quarterly, 48(1), 85-100. 